\title{
Espacios del mal, clichés y silencios narrativos en la crónica de inmigración latinoamericana actual*
}

\author{
Patricia Poblete Alday ${ }^{*}$
}

\begin{abstract}
Resumen
Sobre la hipótesis de una cierta continuidad -en términos de estrategias narrativasentre el relato fantástico y la crónica actual sobre la inmigración en Latinoamérica, el presente artículo analiza dos aspectos particularmente llamativos en esta última, y que se corresponden con el considerado "fantástico semántico" o de contenido, y con el "fantástico del discurso": el mal lugar, y el uso de las expresiones clichés y de los silencios narrativos, respectivamente. Para ello, nos servimos de los aportes teóricos en materia de relato fantástico, en dos momentos: su formulación "canónica", desde el señero trabajo de Todorov (1968), y sus reformulaciones en la época contemporánea, al alero de los avances tecnológicos que modifican nuestra concepción de "lo real". Finalmente, planteamos cómo los aspectos éticos adquieren una relevancia capital en la configuración del mundo narrado en estas crónicas y, por consiguiente, también en nuestra visión del "mundo real”.
\end{abstract}

Palabras clave: Crónica narrativa, inmigración, mal, relato fantástico.

\section{Evil places, clichés and narrative silences in contemporary crónica about current latin american immigration}

\begin{abstract}
On the assumption of some kind of continuity (in terms of narrative strategies) between the fantastic story and the current chronicle of immigration in Latin America, this article analyzes two striking aspects in this last one: the "evil place", and clichés and "narrative silences", which correspond to the so called "fantastic from the semantic" (or content), and the "fantastic from the language", respectively. On this aim, we use the theoretical contributions on fantastic story in two moments: its "canonical" formulation, from Todorov's landmark work (1968), and its reformulations in the contemporary era, when the technological advances modify our conception of "reality". Finally, we propose how the ethics acquire a capital relevance in the configuration of the world narrated in these chronicles and, consequently, also in our vision of the "real world".
\end{abstract}

Keywords: Narrative chronicle, Immigration, Evil, Fantastic stories.

Recibido: 21/04/2016

Aceptado: 21/08/2016

Parte de la investigación NTI-UAHC/2015 “Crónicas sobre la inmigración contemporánea en América Latina: figuras, espacios y desplazamientos de lo monstruoso”, y del proyecto FONDECYT Regular $\mathrm{N}^{\circ} 1160027$, de los cuales la autora es investigadora responsable.

Chilena. Periodista de la Universidad de Chile y Doctora en Literatura Hispanoamericana por la Universidad Complutense de Madrid. Profesora Titular Universidad Academia de Humanismo Cristiano. Santiago, Chile.ppoblete@academia.cl 
La locación es esta: una típica vivienda sureña estadounidense, hecha de delgados tablones de madera (es decir, crujiente); con dos cuartos centrales rodeados por un pasillo donde suelen ubicarse las (también crujientes) mecedoras para pasar las tardes. La pintura de los muros es verde y está descascarada. En el dintel principal del porche cuelga un cráneo de vaca. Al lado de la nave central, hay unas cien latas de cerveza estrujadas. El piso está salpicado de manchas sospechosas, de residuos y de aserrín. Huele a humedad y a materia orgánica en descomposición. Hay jirones de ropa. Basura. Tablones de madera. Oscuridad (Martínez 120-121).

La locación, subraya el narrador, pide a gritos una película de terror. Y, de cierta forma -una forma real, concreta, y por lo tanto, más macabra aún que la ficcional- la obtiene. El narrador, eso sí, no es un guionista de bajo presupuesto ni un epígono de Stephen King; el narrador es un periodista, el joven salvadoreño Óscar Martínez, y lo que aquí retrata no es un set de filmación, sino el rancho La Victoria, a las afueras del pueblo de Gregorio Méndez, Tabasco; en la frontera entre México y Guatemala. Allí, el 3 de julio de 2009, fueron liberados 52 indocumentados centroamericanos que llevaban una semana en poder de Los Zetas. Los encontraron en estado de shock: hacinados, hambrientos, vejados; todos con una franja morada en la espalda baja, producto de los tableos, que son tanto un método de tortura como una rúbrica de esta banda.

\section{Concepciones de lo fantástico}

Tras los señeros estudios de Vax (1965), Todorov (1968) y Caillois (1970), poco se había dicho sobre la naturaleza y la nomenclatura del relato fantástico. En general, y durante bastante tiempo, los críticos y estudiosos de la literatura aceptaron y aplicaron las propuestas analíticas de aquellos (bastante coincidentes entre sí); acotándose su debate y problematización a aspectos bastante específicos. Respecto a las coincidencias, los tres críticos refieren la esencia del fantástico como un "quiebre" o una "rajadura" dentro de lo que consideramos normal o cotidiano. Esto es: un mundo "otro" irrumpe en lo real, haciendo tambalear sus cimientos. Las diferencias entre los citados autores son bastante menores, por ejemplo: la identificación de los temas/motivos del género, o los límites aléticos y epistémicos que rigen entre los distintos órdenes o mundos posibles que integran la diégesis. En cualquier caso, el mundo referido -el "real", 
que sirve como punto de comparación respecto a aquel estado de cosas "anormal" que nos invade y perturba en el relato fantástico- es el delineado por el racionalismo del siglo XVIII, para el que la mente humana es sinónimo y garantía de orden, progreso y felicidad.

Sobre esa cosmovisión, y contra ella, se instala lo fantástico, que "supone la solidez del mundo real, pero para mejor devastarlo" (13). Para nuestro análisis posterior, es importante notar cómo, dentro de esta lógica, lo "real", lo "normal", equivalen a "lo bueno", mientras que lo otro, lo ajeno y desconocido, aquello que no podemos racionalizar ni dominar, se identifica con el mal. "La producción de lo fantástico supone la escenificación del 'Mal'” (47), señala Víctor Bravo (1987), y aunque su enfoque apunta más hacia el sentido funcional del término, ${ }^{1}$ veremos luego cómo esta afirmación cristaliza de forma rotunda también desde el punto de vista ético.

La concepción de lo fantástico es claramente historicista: depende tanto de las concepciones de lo real como de los miedos y preocupaciones de cada época. Los relatos de terror de los siglos XVIII y XIX, por ejemplo, traducían el espanto de ver cómo la regularidad, el orden del mundo basado en la ciencia experimental, cedía al asalto de fuerzas irreconciliables, nocturnas y demoníacas. Pero en el siglo XX, a la luz de los cambios sociales y los avances científicos que han modificado de forma radical lo que concebimos como "realidad", y ante la evidencia de que el sueño de la razón también produce monstruos, se ha vuelto necesario repensar la esencia y los límites de lo fantástico. Lo que ayer era imposible, hoy es cotidiano; lo que antes era desconocido, ahora es común; lo que antaño nos perturbaba, hoy nos divierte. Pero, también, aquello que creíamos conocido nos muestra facetas nuevas y desconcertantes, partiendo por la misma naturaleza humana.

Varios estudiosos han propuesto enfrentar esta extrema movilidad del término "fantástico" prestando atención no solo a su componente semántico -el mundo narrado y sus personajes- sino a su dimensión discursiva. Desde esta, el extrañamiento puede surgir también desde los juegos del lenguaje (Campra, 2008), a veces incluso prescindiendo de los temas fantásticos. Así, la literalización del sentido figurado, la adjetivación

Víctor Bravo trabaja el aspecto lingüístico de la alteridad, en tanto sistema que se opone a la pretendida transparencia del lenguaje. El lenguaje, las palabras, al ser una realidad 'otra', distinta de la realidad del mundo, constituye de por sí una cristalización de la otredad, por lo que la misma producción de lo literario supone la puesta en escena de la alteridad. 
connotada, la nivelación narrativa de lo natural y lo sobrenatural, la elusión del término designativo, la antropofomización de la sinécdoque (Roas, 2011), e incluso el cliché o la frase hecha, y el silencio narrativo, son recursos retóricos característicos de un relato fantástico que hoy parece menos interesado en demostrar la evidencia de lo sobrenatural, que en exhibir la anormalidad de la realidad, para revelar que nuestro mundo "no funciona como creíamos" (Roas 107).

Y es que la torsión del lenguaje sobre sí mismo, así como su inherente opacidad, parecen adecuados para iluminar -valga la paradoja- esas zonas siniestras de lo real, aquella suerte de espantoso que afecta las cosas conocidas y familiares: lo unheimlich, como lo llamó Freud (1919), y que está a la base, precisamente, del relato fantástico. El texto, entonces, se hace relato de la liberación de aquellos impulsos atávicos, pre-racionales, que habitan dentro de cada persona y que han debido domesticarse para vivir en sociedad, según el ideal iluminista. Sin embargo, ese texto, en la época contemporánea, no tiene por qué ser un relato de terror fantástico. Puede ser, perfectamente, una crónica que aborde una de las tantas manifestaciones de la violencia humana desatada. Por ejemplo: las pandillas en Nicaragua y El Salvador; los narcos en México, Colombia y Guatemala; las miles de migrantes violadas y atrapadas en las fronteras, psicópatas, asesinos, dictadores, sicarios... A la luz de las historias que narran estas crónicas, parece necesario asumir que las formas del mal que lo fantástico narrativizaba ya no son lo extraño a la razón, ni lo ajeno a lo humano, sino que más bien la monstruosidad ética ha pasado a ser parte de la normalización de las sociedades posmodernas. La lectura de estas historias cuestiona y modifica nuestra concepción de lo real, no ya desde lo materialmente factible, sino desde lo éticamente concebible: si los periódicos dan cuenta de una masacre de migrantes, no dudamos de que el hecho se haya producido, sino que nos cuesta creer que exista gente capaz de gozar torturando al prójimo; no dejamos de asombrarnos y espantarnos ante las manifestaciones de la crueldad humana. La resistencia que experimentamos a creer en la veracidad de episodios brutales -pensemos en los comentarios que suscitan: "no puede ser", "imposible", "jamás me lo hubiese imaginado" - habla precisamente de esta "rajadura" de la realidad: estas crónicas nos muestran que "lo real" tiene bastante más matices y recovecos de los que conocemos, y que buena parte de ellos son oscuros y peligrosos. El mal ya no está "allá afuera", ya no es "lo desconocido": es parte de nuestra realidad cotidiana, de nuestra propia naturaleza. 
Es en este reconocimiento donde, según proponemos, una buena parte de la crónica narrativa que hoy se escribe, confluye con la esencia (y la herencia) de la literatura fantástica. ${ }^{2}$ Sobre esta hipótesis, y atendiendo a la distinción antes referida entre fantástico de contenido y de lenguaje, revisaremos someramente aquí algunas manifestaciones de cada una de ellas: el mal lugar, y el uso de clichés y silencios narrativos.

\section{Del mal lugar al mal liberado}

El espacio ominoso, o "mal lugar", como lo ha designado uno de los maestros del fantástico, Stephen King (1981), es uno de los tópicos más recurrentes del género: “Cuando llegamos a casa y echamos la llave a la puerta, nos gusta pensar que estamos dejando fuera los problemas. La buena historia de horror acerca del Mal Lugar nos susurra que no estamos dejando fuera el mundo, sino que nos estamos encerrando... con ellos" (389).

El mal lugar signa un espacio maldito, por lo general donde ocurrieron episodios aciagos, que han quedado "cargados" con una energía negativa capaz de desencadenar nuevas tragedias o, por lo menos, de aterrorizar a los incautos. El castillo sumido en la bruma, la casa encantada, la habitación misteriosa, el pueblo abandonado, son conocidos ejemplos del espacio ominoso. Pero cuando lo siniestro sale de los márgenes de lo fantástico y se instala en la cotidianeidad de lo real, el mal lugar se mimetiza con el entorno: es el barrio de las favelas donde las balas tienen voluntad propia; es el despacho de un dictador que ordena ejecutar a sus adversarios mientras humilla a sus subordinados; es el albergue infantil donde una niña muere por desidia de las autoridades. Es, para acotar nuestra exposición, el extenso corredor mexicano, derrotero de migrantes ilegales que acaban siendo presa y mercancía de los Zetas.

Quizás haya sido el periódico salvadoreño El Faro, editado en plataforma online, el pionero en narrar de forma sistemática los horrores de la migración centroamericana, generando con ello un foco noticioso a nivel continental. Desde el proyecto En el camino -

Comprendemos esta continuidad propuesta entre la crónica contemporánea y la literatura fantástica de terror no como una "sustitución" de la primera respecto a la segunda, sino más bien como una particularidad actual de un género o modo discursivo que hemos identificado como proteico, híbrido e interdisciplinar, siempre en sintonía con las condiciones sociohistóricas en las que nace y es recibido (Poblete Alday, 2013, 2014). 
encabezado por el citado Martínez, quien acompañó durante más de un año a los indocumentados en su periplo de sur a norte- este medio ha utilizado la investigación participante o camuflada. Sus primeros frutos editoriales, Los migrantes que no importan (2010) y Crónicas negras (2014), son compilaciones de textos donde la primera persona no es sino el puente para que el lector se sienta implicado, o al menos afectado, por los horrores que se narran. No hay espacio para la reflexión poética, las florituras retóricas ni los recuerdos personales del periodista. La contundencia de los hechos -del "marco referencial", para decirlo en términos de teoría literaria- hace no sólo innecesario, sino incluso obsceno, cualquier arranque lírico o autorreferente.

Desde estas crónicas, el territorio mexicano se revela como un campo minado; pavoroso revés de la postal turística y los discursos oficiales. Sobre la simbólica antropológica delineada por Gilbert Durand (1979), es posible identificar varios arquetipos o manifestaciones por las cuales el territorio adquiere connotaciones malignas. El primero remite a una geografía viva e implacable, que dificulta el avance, en el mejor de los casos, o lo impide del todo. Primero, selvas espesas e impenetrables, repletas de alimañas. Luego, caminos escarpados, sinuosos como serpientes, que atraviesan túneles negros "donde no es posible verse ni la mano frente al rostro" (Martínez 76), al tiempo que bordean precipicios interminables, flanqueados de rocas frías y enormes "como cabezas olmecas" (Ibíd.). Finalmente, está el desierto, considerado desde las antiguas religiones "la morada del príncipe de los infiernos, el reino mismo de la Nada o la emergencia sensible del abismo sin fondo y sin fundamento" (Trías 35). El desierto, donde el cliché del averno se vuelve real:

Caminamos por piso de piedras sueltas, siguiendo las vías. Es un sitio más apocalíptico. Seco, yermo. Pasamos al lado del famoso basurero, un punto esperpéntico de asaltos y violaciones. Un basurero al aire libre repleto de bolsas y cartones multicolores que vuelan con el viento y se prenden en las verjas de los ranchos. Parece la escena que queda luego de una potente explosión. (61)

Y de forma aún más sobrecogedora, en un texto de Marcela Turati, que resultó finalista del Premio de Crónica de la Fundación Nuevo Periodismo Iberoamericano en 2003: 
Secos como ramas. Así quedaron, esparcidos en los pedazos de desierto. Desde el tercer día de su caminata por el desierto de Arizona, uno por uno, fueron vencidos por el infierno. Uno, desesperado, abrazó un cactus y flageló su cuerpo con las espinas; Edmundo Adrián, de 23 años, veracruzano de Coatepec, se desvaneció bajo la sombra de un matorral, refresco inútil. Frente a él, su tío José Isidro lo vio que apretó los párpados, lloró dos lágrimas y expiró. Arnulfo, el padrino de Edgar, también de Coatepec, tierra caliente y húmeda, de cafetales, tampoco aguantó. Alcanzó a esconder su cuerpo en el hoyo de un tronco. Los 47 grados derritieron su desesperación. Vino un grito y una convulsión. ("Muerte en el desierto" 521)

En este paraje, las coordenadas se emborronan, y el mismo lenguaje que las demarca pierde referencialidad. ¿Hacia dónde el norte, hacia dónde el sur? Elegir un camino es tentar a la suerte, y poner la propia vida en la ruleta. La única señalética la conforman "un par de señales que guían a ranchos perdidos en la nada" (Martínez 177), como precisa el cronista, tan a la deriva como los inmigrantes a los que acompaña. La pérdida de referentes, sin embargo, no es únicamente geográfica: “Aquí se camina entre muertos, la vida se relativiza como un valor que se menea en una cuerda floja. Matar, morir, violar o ser violado pierden sus dimensiones. Es rutina. Punto de referencia: aquí, en esta piedra, violan; allá, en ese arbusto, matan" (54).

Esto se evidencia en lugares como La Arrocera, Chiapas, considerado popularmente un lugar maldito; un "vertedero de maldad impune" (48). Como en las inmediaciones de Mexicali, Baja California, donde nace el mito del "árbol de los calzones": un arbusto del desierto decorado con bragas de las migrantes que en su intento de ingresar a los Estados Unidos han sido violadas. Sus prendas son trofeos del agravio. Se le llama mito, aclara el cronista, no porque sea una leyenda urbana, sino porque no se trata de un matorral en concreto, sino de una práctica normalizada. Y se evidencia, en fin, en algo tan cotidiano como los centros botaneros, bien llamados antros, donde se concentra el narco y la prostitución de los pueblos fronterizos.

Antesala del espejismo americano, el paisaje deviene laberinto maze o perdedero: todas sus salidas desembocan en murallas. Una natural, la del río Bravo; otra simbólica, pequeña y metálica, construida en 1994 con desperdicios de la Guerra del Golfo (1991); y otra, definitiva, funcional e 
imponente, erigida en 1997: un monstruo de 22.500 metros de barrotes de cuatro metros de altura. Quienes fracasan en su paso, o son deportados, o merodean por la frontera como si esta fuese un purgatorio, y ellos, almas en pena condenadas a repetir una y otra vez el mismo periplo. Porque a medida que las rutas se saturan de narcos y coyotes, la frontera se va cerrando, y todo aquel que de una u otra forma lucra con la migración, se moviliza en busca del nuevo y transitorio pasadizo secreto. Así, si antes los indocumentados llegaban a Tijuana y Tecate de camino a Estados Unidos, ahora estos lugares son rutas muertas; ciudades de deportados que apenas se detienen allí antes de regresar a sus ciudades de origen. En muchas localidades, sólo van quedando algunas casas como vestigio de la vida que alguna vez albergaron: "Es como si hubieran dejado de existir. Aquí, en esta zona desértica de la frontera de México con Estados Unidos, la gente habla de estos pueblos como quien habla de un campo yermo. Como hablar de allá donde no hay nada, de un lugar al que no tiene sentido ir. Pueblos fantasmas los llaman" (227).

Y el paisaje le hace justicia a ese mote. Llanos deformes y oscuros, "con algunos arbustos desérticos y escombros silueteados" (210), donde lo único que se escucha es el silbido del viento. Donde el termómetro oscila entre los 50 grados en verano, y los cinco bajo cero en invierno, recordando uno de los tramos más temidos por los viajeros: la llamada cordillera del Hielo, en la Sierra Madre Oriental, cuyo tránsito (en tren, el famoso tren carguero apodado La Bestia) demora entre 10 horas y 2 días. Si logran superar este trayecto, el alivio dura poco: entre Tamaulipas y San Fernando les esperan los Zetas, que han encontrado en el secuestro de inmigrantes una forma rápida y sencilla de conseguir algo de dinero. Los ranchos -como el que se describe al inicio de este texto- se vuelven salas de tortura a la espera de un rescate, o antesala de fosas clandestinas. ${ }^{3}$

El mal lugar, en estas crónicas, se desmarca de las fronteras geográficas y se vuelve una atmósfera generalizada; una suerte de virus intersticial y fluido, según la homología de Baudrillard (65). El mal liberado es inaprehensible e irreductible; a lo más podemos identificar sus circuitos -como, por ejemplo y según vemos en las siguientes imágenes, los que marcan la ruta del migrante- que a su vez son también móviles y caprichosos. Mientras estuvo confinado en un espacio determinado -una 
casa, un castillo, un pueblo- el mal era algo excepcional, conjurable y reductible; liberado, en cambio, se naturaliza y se vuelve más difícil de reconocer. Al ser parte de estas sociedades de violencia, nos volvemos víctimas potenciales e involuntarias, y el miedo pasa a ser un elemento constitutivo de la ciudadanía (Rotker13-18), saltando de los relatos de ficción a la crónica de sucesos.

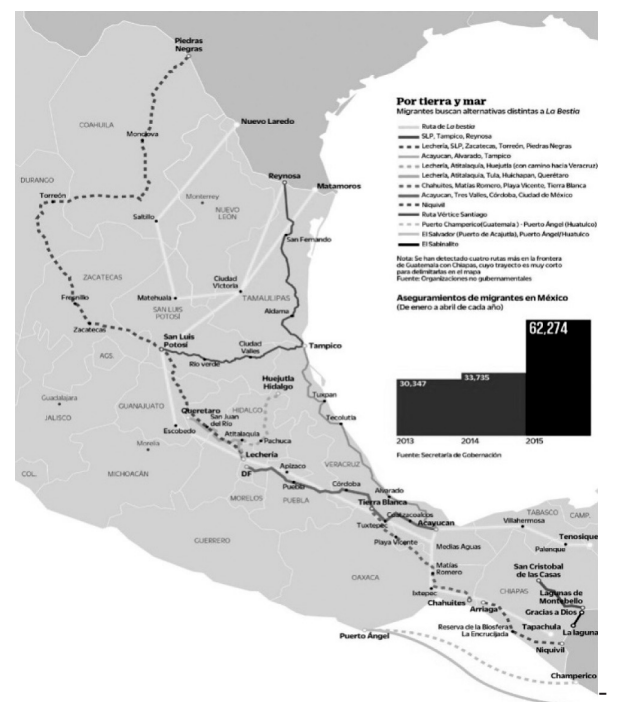

Imagen 1. Rutas migrantes: “La Bestia”, Golfo de México. Fuente: La voz de Arizona

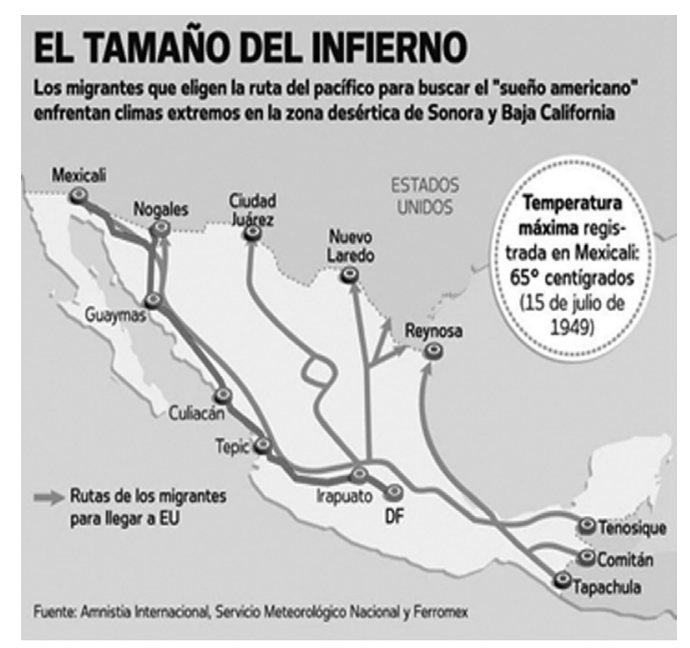

Imagen 2. Rutas migrantes: "El Diablo", Pacífico Norte.

Fuente: El Universal 


\section{Clichés y silencios resignificados}

Pese a que su teoría sobre lo fantástico es más reconocida por la identificación de los temas del género, Todorov sí enunció las posibilidades de este a nivel del enunciado. Si bien no profundizó en ellas, en algunas páginas de su Introducción a la literatura fantástica menciona la recurrencia de la hipérbole y la ambigüedad en la construcción de este tipo de relatos: "lo sobrenatural nace del lenguaje; es a la vez su prueba y su consecuencia" (99). De forma similar, Irène Bessière señaló que para expresar lo fantástico se tiende lingüísticamente a la paradoja, al oxímoron y a la ambigüedad (1984), pero fue enfática en señalar que estos recursos, al igual que las temáticas y motivos del género, dependían del contexto histórico, social y cultural: "No existe un lenguaje fantástico en sí mismo. Según las épocas, el relato fantástico se lee como el reverso del discurso teológico, iluminista, espiritualista o psicopatológico, y no existe más que por ese discurso que descompone desde el interior." ("El relato fantástico..." 87). En este sentido, Rosalba Campra (2001) señala que para producir el efecto fantástico ya no es tan necesaria la aparición de un fenómeno imposible (sobrenatural), porque la transgresión se genera mediante la irresoluble falta de nexos entre los distintos elementos de lo real. Esto puede lograrse con una sintaxis dislocada, que desestabilice las reglas de causalidad que rigen el mundo "real" y, con ello, el paradigma racional que está a la base de nuestra sociedad.

En este apartado veremos dos modos, en apariencia opuestos, en los que el trabajo sobre el lenguaje genera o intensifica el efecto de "extrañamiento" tradicionalmente asociado al fantástico, pero ahora plasmados en la crónica. El primero es el cliché o la frase hecha; el segundo es el silencio narrativo.

En el proceso de narrar los aspectos ominosos del territorio mexicano, los cronistas recurren con frecuencia a las frases hechas. Por ejemplo, y para continuar con la lógica geográfica trazada en el apartado anterior, en su afán de evitar la zona de los Zetas, los centroamericanos han buscado rutas alternativas; una de ellas es la del Pacífico, a lomos de otro tren carguero, el de Ferromex, apodado El Diablo (Imagen 2). En su destino a Mexicali, este tren cruza Sonora y Baja California, exponiendo a sus pasajeros a condiciones climáticas también insoportables, aunque en el otro extremo del termómetro. De ahí el nombre de la máquina: a 
quienes se animan a abordarla, les advierten que "van a descender al infierno". El sentido figurado se literaliza, lo que se aprecia en el relato de Edgar, un guatemalteco entrevistado por el diario El Universal, quien cuenta que una vez que se acaba el agua y comienza la insolación, la travesía se vuelve desesperante. Dice que es como meter la cabeza a un horno encendido; que el organismo deja de producir saliva. Dice que él debió beber de su propia orina para aguantar un trayecto de casi diez horas. Dice: "La arena te pega en los ojos. Quisieras bajarte, buscar agua para mojarte; el viento lejos de refrescarte te ahoga, hasta cuando hablas sientes vapor en la sangre." Dice que quien no lo ha vivido, no sabe; que no puede siquiera comenzar a imaginar (El Universal, 14/07/2013).

Otro cronista llama a Tamaulipas un “agujero negro” (Padgett 153). Otra define a Juárez como "un cementerio público, [...] una moderna necrópolis" (Turati, “Guerra contra el luto” 234). El pueblo de Las Chepas, en el estado de Chihuahua, está situado, para otro, "en medio de [un] triángulo de las Bermudas" (Martínez 229); mientras que en Coatzacoalcos ("escondite de la serpiente" en náhuatl), asegura, "se respira el miedo" (110). Las carreteras del norte son "un camino de sombras" (Osorno 153); el valle de Tamaulipas es un "laberinto sin centro" (242). Las celdas sobrepobladas son "un círculo dantesco" (Bianchini 86), o "un horno" (91); el silencio de la noche es "sepulcral" (102); los migrantes son "muertos vivientes" (120) que caminan "como autómatas" (264), o "como un zombie" (265). Los cronistas audiovisuales coinciden en este campo semántico: el mexicano Rodrigo Reyes tituló su documental sobre la frontera norte Purgatorio (2013), mientras que el premiado largometraje de Diego Quemada-Díez, centrado fundamentalmente en la frontera sur, se llama La jaula de oro (2013). Desde una perspectiva más analítica y menos testimonial, los periodistas Rafael Barajas y Pedro Miguel enarbolan la misma retórica: “Comparadas con el infierno que viven [en México] los ciudadanos, las alucinaciones de El Bosco son viñetas infantiles." (12).

Los propios cronistas son conscientes de la imposibilidad de huir del cliché. Al describir un paraje cercano a San Fernando -donde se encontró una fosa clandestina con cuerpos de casi 200 migrantes, en 2011- Diego Enrique Osorno (2014) reflexiona:

A esta hora -la hora mágica, le dicen los fotógrafos poetas al atardecer y su luz perfecta- hay un fulgor desafortunado iluminando las alas de las nauseabundas aves carroñeras que 
parecen un cliché inventado para el cierre de este libro, pero es cierto -y es patético que sea así- que están aquí, frente a ti. No fotografías de cerca a los zopilotes. No quieres añadir más horror a las brechas de San Fernando [...]. (315)

Aquí la frase hecha se ha convertido en imagen manoseada, pero el sentido del cliché se mantiene. Otro ejemplo de lo mismo, acaso con menos conciencia crítica, lo encontramos en el episodio del relato de Flaviano Bianchini (2016), que narra su travesía mexicana de sur a norte en condiciones de migrante ilegal. Él y su grupo han ingresado a Estados Unidos, pero aún no llegan a su destino; aún no están a salvo, y deben esconderse dentro de los túneles de una mina abandonada ante la presencia de una patrulla. Cuando pasa el peligro: "Se encienden las luces y subimos lentamente hasta el túnel de entrada. Cuando yo salgo, la luz brillante al fondo me parece una metáfora. Todavía seguimos en la oscuridad, pero vemos una luz al fondo de este túnel. Solo tenemos que resistir uno o dos días más" (278).

Ejemplos como estos muestran que el cliché, en estas crónicas, es menos falta de imaginación de quien escribe, que incapacidad de las palabras, que no saben decir el horror que escapa a la razón. Así entendido, e irónicamente, el cliché forma parte de la 'retórica de lo indecible' (Bellernin-Noêl, 2001), característica del género fantástico, en la medida en que -a fuerza de uso y desgaste- ha dejado de designar la experiencia a la que refiere. Pero, al confrontarnos con la literalidad del sentido figurado, la crónica -al menos esta que aquí nos ocupa- devuelve al lenguaje su espesor referencial, generando al mismo tiempo el efecto que antes considerábamos "fantástico": el horror. Así se entiende la insistencia en adjetivos como "infernal", "espantoso", "monstruoso", "diabólico", "pavoroso", "espeluznante", "terrible”, etc.

En este mismo sentido se explica la abundancia de los silencios textuales, que adquieren una fuerte carga semántica en la medida en que señalan los huecos en la realidad referida. Silvia Molloy (1991) hizo notar que en la literatura fantástica es imprescindible prestar especial atención a lo que NO se cuenta, a lo que se deja de lado y se reprime (lo siniestro). Asimismo, Rosalba Campra (1991) hace hincapié en el juego que establece el relato fantástico con los desequilibrios entre lo dicho y lo no dicho. Estos silencios del texto, indica Campra, no pueden ser llenados, ya que el "silencio en la trama del discurso sugiere la presencia de vacíos en la trama de la realidad" (52). "Puntos finales que 
abruptamente cierran una frase que no se ha cerrado conceptualmente, gramaticalmente. Puntos suspensivos que dejan colgando en el vacío del renglón una palabra que no sabe hacia dónde dirigirse... Tematizaciones y caídas del discurso son formas del silencio con que el texto construye su sentido fantástico" (Territorios de la ficción. Lo fantástico 115).

En las crónicas que estudiamos, el silencio también tiene un rol rotundo y elocuente; sin embargo, no se trata, como en el relato fantástico, de lagunas de indeterminación: el sentido de lo omitido aquí es claro. Por ejemplo: cuando, tras relatarnos una serie de conversaciones telefónicas con dos hermanos migrantes, estos dejan de responder sus llamados, tanto el cronista como los lectores comprendemos que han sido capturados en un secuestro masivo (Martínez 43). El sonido isócrono del ring sin contestar también es evidencia suficiente de que el coyote chilango que es perseguido por violar las reglas de la frontera ha sido apresado por quienes las imponen:

-Heeeey... Sssss.

Es apenas un susurro.

— ¿Chilango? ¿Chilango? - preguntó en voz alta.

-Heeeeey... Ayúdame. Ssssss. Me agarraron. Aquí andan. Ayúdam... Tut, tut, tut. (150)

El sutil recurso de la alusión adquiere aquí una contundencia feroz, lapidaria; como cuando otro cronista describe la escena de un crimen donde hay sangre, luz mortecina, dos casquillos, pero ningún cadáver, y se pregunta qué habrá sucedido, para responderse de inmediato: “Quién sabe. Fantasmas" (De la Fuente 44). O cuando delinea una masacre que se perpetra desde un automóvil, en apenas unos segundos:

Escenas fugaces e incomprensibles. Esa es la materia de la que se componen los campos de la violencia. No son zonas de traqueteos de metralleta ni de hombres y mujeres en fuga constante. Son silencios y ocasos que se rompen por esa fugacidad en las banquetas donde los niños juegan, en las esquinas donde los jóvenes conversan, en las tiendas donde las madres despachan. (Martínez 34)

Lo indecible, además, tiene en estas crónicas una dimensión pragmática, igualmente feroz: los periodistas que cuentan demasiado, 
son asesinados. ${ }^{4}$ El no decir se vuelve una estrategia de sobrevivencia; el horror que en el texto fantástico era "indecible" aquí deviene "impublicable", ya que su relato contiene las semillas de su propagación. Explica Osorno:

[...] es común que las notas contengan descripciones abundantes acerca del tipo de cadáver encontrado (decapitado, descuartizado, ejecutado...), del tipo de coche en el que iba el muerto y del número de sesos regados en el pavimento, pero se contará poco sobre el marco del cual presuntamente provendrían sus posibles asesinos. [...] Esta cobertura no proviene de la ingenuidad de la prensa. La pornografía de la violencia se ha convertido en la única forma en que el periodismo mexicano puede registrar hechos del narco y al mismo tiempo autoprotegerse, sobrevivir. (294-295)

\section{Conclusiones}

Varios autores han hecho notar que el fantástico, antes que un género, constituye una categoría epistemológica (Alazraki, 1983; Cortázar, 1996; Pampa, 1999; Roas, 2011), en tanto expone y cuestiona nuestras formas de representar la realidad. Lo imposible en estos relatos es un ataque contra la causalidad natural, y se entiende desde su dimensión material y metafísica (viajes en el tiempo, muertos que vuelven a la vida, autómatas dotados de voluntad, etc.). Ante esta "rajadura" de las leyes naturales, tanto el lector como los personajes experimentan extrañamiento, resistencia e incredulidad, cuando no miedo u horror.

La reacción del lector de estas crónicas, así como de sus protagonistas, es similar. Nos cuesta trabajo creer que aquello que se nos muestra es efectivamente parte del mundo real; nos asombra la capacidad humana para hacer el mal; nos espanta la evidencia de la cercanía del peligro. Sin embargo, la imposibilidad aquí es de carácter ético y moral: son las leyes axiológicas las que resultan vulneradas. El asombro y el horror con el que reaccionamos ante ello son claros indicativos de que esta dimensión

\footnotetext{
Según Reporteros Sin Fronteras, en 2017 el ranking de los lugares más arriesgados para ejercer el periodismo lo encabezó Siria, donde fueron asesinados 12 reporteros. Le siguió México, con 11. Nótese que la diferencia en las cifras es mínima, siendo que el primero es un país en guerra declarada, y el segundo no. Para más información, véase $<$ https://rsf.org/es/periodistas-asesinados $>$
} 
valórica es sustancial en la constitución de la realidad, y por lo tanto también debe considerarse a la hora de redefinir lo fantástico al alero de las transformaciones sociales.

Creemos que el enfoque analítico aquí adoptado permite visualizar de manera concreta las relaciones entre periodismo y literatura; comprendiéndolas, más que "préstamos" o "contaminaciones" términos que suponen compartimientos estancos- como una dinámica constante en la cual ambas prácticas se funden, dando cuenta de sus transformaciones históricas. Así, podemos comprender la crónica narrativa no solo como un modo textual, sino como una forma de conocer el mundo; por lo mismo, y en el caso que aquí revisamos, nos ha permitido tanto situar el ejercicio periodístico más allá de la simple coyuntura informativa, y pensar la lógica de lo fantástico fuera de los límites de la ficción.

\section{Referencias bibliográficas}

Alazraki, Jaime. En busca del unicornio: los cuentos de Julio Cortázar. Madrid, Gredos, 1983.

Barajas, Rafael y Pedro Miguel. "Relaciones entre poder político y crimen organizado. El naufragio del Estado mexicano”. Le monde diplomatique, México ¿un Estado fallido? Santiago, Editorial Aún creemos en los sueños, 2015, pp. 9-15.

Baudrillard, Jean. La ilusión del fin. La huelga de los acontecimientos. Barcelona, Anagrama, [1992] 1993.

Bellernin-Noèl, Jean. "Notas sobre lo fantástico (textos de Théophile Gautier)". Teorías de lo fantástico. David Roas. Comp. Madrid, Arco Libros, 2001, pp. 108-140.

Bessière, Irène. "El relato fantástico: forma mixta de caso y adivinanza". Teorías de lo fantástico. Comp. David Roas. Madrid, Arco Libros, 2001, pp. 83-104.

Le rècit fantastique. París, Libraire Larousse, 1984.

Bianchini, Flaviano. El camino de la bestia. Migrantes clandestinos a la búsqueda del sueño americano. Logroño, Pepitas de Calabaza, 2016.

Bravo, Víctor. Los poderes de la ficción. Caracas, Monte Ávila, 1987. 
Callois, Roger. Imágenes, imágenes... (Sobre los poderes de la imaginación). Barcelona, Edhasa, 1970.

Campra, Rosalba. Territorios de la ficción. Lo fantástico. Salamanca, Renacimiento, 2008.

"Lo fantástico: una isotopía de la transgresión”. Comp. David Roas. Teorías de lo fantástico. Madrid, Arco Libros, 2001, pp. 153-191. “Los silencios del texto en la literatura fantástica”. El relato fantástico en España e Hispanoamérica. Ed. Enriqueta Morillas Ventura. Madrid, Siruela, 1991, pp. 49-7.

Cortázar, Julio. "Del sentimiento de lo fantástico". La vuelta al día en ochenta mundos. México, Siglo XXI, 1996, pp. 69-75.

Duran, Gilbert. Las estructuras antropológicas de lo imaginario. Madrid, Taurus, [1979] 1981.

De la Fuente, Daniel. “Partes de guerra”. Generación ¡Bang! Nuevos cronistas del narco mexicano. Ant. Juan Pablo Meneses. México, Temas de Hoy, 2012, pp. 37-55.

Freud, Sigmund. Lo ominoso. México, Letracierta, [1919] 1978.

King, Stephen. Danza Macabra. Madrid, Valdemar, [1981] 2006.

Martínez, Óscar. Los migrantes que no importan. En el camino con los centroamericanos indocumentados en México. Barcelona, Icaria, 2010.

Molloy, Silvia. “Historia y fantasmagoría”. El relato fantástico en España e Hispanoamérica. Ed. Enriqueta Morillas Ventura. Madrid, Siruela, 1991, pp. 105-114.

Osorno, Diego Enrique. La guerra de Los Zetas. Viaje por la frontera de la necropolítica. México, Debolsillo, [2012] 2014.

Padgett, Humberto. "Los desaparecidos de Tamaulipas". Generación ¡Bang! Nuevos cronistas del narco mexicano. Ant. Juan Pablo Meneses. México, Temas de Hoy, 2012, pp. 153-172.

Pampa O., Arán. El fantástico literario: aportes teóricos. Córdoba, Narvaja, 1999.

Poblete Alday, Patricia. "Las narrativas del Yo en la crónica contemporánea". Anales de Literatura Hispanoamericana, no. 43, 2014, Universidad Complutense de Madrid, pp. 241-254. 
"Hibridez y tradición en la crónica latinoamericana contemporánea: los textos de Rafael Gumucio". Textos Híbridos, vol. 3, no. 1, julio 2013, http://www.escholarship.org/uc/item/4z85s4w0

Quemada-Díez, Diego (Dir. y guión). La jaula de oro. Largometraje. México, Machete Producciones, 2013. Color, $108 \mathrm{~min}$.

Reyes, Rodrigo (Dir. y guión). Purgatorio: Viaje al corazón de la frontera. Documental. México, La Maroma Producciones, 2013. Color, $80 \mathrm{~min}$.

Roas, David. Tras los límites de lo real. Una definición de lo fantástico. Madrid, Páginas de Espuma, 2011.

Rotker, Susana (Ed.). Citizens of fear. Urban violence in Latin America. New Jersey, Rutgers University Press, 2002.

Todorov, Tzvetan. Introducción a la literatura fantástica. Barcelona, Ed. Buenos Aires, [1968] 1982.

Trías, Eugenio. Lo bello y lo siniestro. Barcelona, Ariel, [1982] 2009.

Turati, Marcela: “Guerra contra el luto”. Generación ¡Bang! Nuevos cronistas del narco mexicano. Ant. Juan Pablo Meneses. México, Temas de Hoy, 2012, pp. 227-235.

“Muerte en el desierto". Lo mejor del periodismo de América Latina. VVAA. México, FCE/FNPI, 2006, pp. 521-539.

Universal, El (14 julio 2013). "El Diablo, nuevo tren de migrantes”. El Universal. Consulta online 25/04/2016 <http://archivo. eluniversal.com.mx/estados/2013/impreso/el-diablo-nuevotren-de-migrantes-91663.html>

Vax, Louis. La séduction de l'étrange. París, Presses Universitaires de France, 1965.

VV.AA. Crónicas negras desde una región que no cuenta. México, Aguilar, 2014. 